\title{
Artelogie
}

Recherche sur les arts, le patrimoine et la littérature de l'Amérique latine

5 | 2013

Femmes créatrices en Amérique latine : le défi de synthétiser sans singulariser

\section{(Domestic) Spaces of Resistance: Three Artworks by Anna Maria Maiolino, Letícia Parente and Anna Bella Geiger}

\section{Giulia Lamoni}

\section{(2) OpenEdition Journals}

Electronic version

URL: https://journals.openedition.org/artelogie/5706

DOI: $10.4000 /$ artelogie. 5706

ISSN: 2115-6395

\section{Publisher}

Association ESCAL

\section{Electronic reference}

Giulia Lamoni, "(Domestic) Spaces of Resistance: Three Artworks by Anna Maria Maiolino, Letícia Parente and Anna Bella Geiger", Artelogie [Online], 5 | 2013, Online since 16 October 2013, connection on 20 December 2021. URL: http://journals.openedition.org/artelogie/5706 ; DOI: https://doi.org/ 10.4000/artelogie.5706

This text was automatically generated on 20 December 2021.

Association ESCAL 


\title{
(Domestic) Spaces of Resistance: Three Artworks by Anna Maria Maiolino, Letícia Parente and Anna Bella Geiger
}

\author{
Giulia Lamoni
}

1 Gostaria de agradecer a Anna Maria Maiolino, Anna Bella Geiger, André Parente, e Lívia (Studio Anna Maria Maiolino), pela disponibilização das imagens e pelo apoio generoso. Agradeço também a Luísa Moisio e Annette Stephansen pela sua leitura atenta do texto em inglês. A previous version of this text has been presented at the international conference X Jornadas Internacionales de Estudios de la Mujer / NegotiatingGenderedSpaces, 16-18 May 2012, Facultad de Filología, Universidad Complutense de Madrid.

Participating, as an artist, in the years at the turn of the sixties to the seventies was to deal with another reality, a new social, political, economical and cultural world. A world in which the ideas of abstract modernity did not seem to cope any more ${ }^{1}$ (Anna Bella Geiger in SCOVINO, 2009: 19).

2 As these words by Brazilian artist Anna Bella Geiger suggest, after the 1964 military coup that overthrew president Goulart, the artistic community in Brazil was confronted with the urgency of developing new languages and new ways of making art that engaged with the political, cultural and social reality of the country ${ }^{2}$. It was a period of intense and heterogeneous artistic effervescence, in which experimentation was often associated with the creation of spaces of resistance and with the development of broader relations between art and spectatorship.

In the text Esquemageral da nova objectividade, published in the catalogue of the landmark exhibition "Nova ObjectividadeBrasileira"3 - at the Museum of Modern art of Rio de Janeiro in April 1967 -, artist HélioOiticica described the "new objectivity" as "[...] the formulation of a typical state of the present Brazilian vanguard art" 4 (OITICICA, 1967: 75) and importantly underlined its "[...] approaching and taking a position as to political, social 
and ethical problems"5 (Ibidem). Among the multiple features associated to the varied artistic tendencies drawn together in the "new objectivity", Oiticica also highlighted the inclination towards collective art, the rejection of easel painting, the interest in the object instead, in anti-art and in participation as opposed to "[...] pure transcendental contemplation [...]"6 (Idem: 79). Oiticica wrote that "Today, in Brazil [...], in order to take an active cultural position, one that counts, it is necessary to be against, viscerally against everything that is, in short, the cultural, political, ethical and social conformism"' (Idem: 81).

The "tropicalist moment" (SÜSSEKIND, 2007: 31) of the late sixties, characterized by an outburst of very diverse vanguard artistic productions in theatre, cinema, music and the visual arts - and by the negotiation of a new critical positioning in relation to national myths, foreign influences and hegemonic cultural paradigms ${ }^{8}-$, was marked, in December 1968, by the dramatic deterioration of the country's political situation. Civil demonstrations expressing dissent against the military regime were countered, in fact, by the establishment of the Institutional Act $n^{\circ} 5$, thus by the hardening of repressive policies and censorship. As observed by Roberto Schwartz in 1970, whereas after the 1964 coup the regime somehow "preserved" the cultural production - that developed then in an environment of "relative freedom" (PECCININI, 1999: 152) -, at the end of 1968, " [...] when the student and the public of the best films, theatre plays, music and books already constitute a politically dangerous mass [...]"9 (SCHWARZ, 1970: 281), the control over the arts intensified in a significant way ${ }^{10}$.

5 As a consequence of these circumstances, several artists and intellectuals chose or were forced toleave the country. Although important collective events took place in the years immediately after the IA5 - as the "Salão da Bússola"11 in 1969, "Do corpo à terra"12 in 1970, the "Domingos de criação"13, in 1971 - an important shift occurred ${ }^{14}$. The early seventies, marked by strong repression and political violence, were thus characterized by a new sense of isolation and by the need to articulate radical strategies of resistance, as shown by the conceptual works of artists such as CildoMeireles, Antônio Manuel and ArturBairro and by the analogy of the artist as a "guerrilheiro" fighter developed in those years by critic FredericoMorais ${ }^{15}$ (MORAIS, 1975: 26)

6 Focusing on the Brazilian artistic production of the late sixties and mid-seventies - and drawing on a close reading of three specific artworks by Anna Maria Maiolino, LetíciaParente and Anna Bella Geiger-, this text will look at how space was represented, lived or materialized in the work of these artists. More particularly, it aims to examine how the multiple intersections and negotiations that occur between public and private spaces were critically explored by activating heterogeneous images of the home. Importantly, if the works considered here develop an iconography of the domestic sphere, they also seem to mobilize the whole polysemic spectrum of the words home and domestic - referring for instance to one's dwelling and country - and eventually play with it.

7 By reading these works in conjunction, I intend to address - in a comparative perspective and without any pretension to be exhaustive - the complexity and specificity of the positions they embody through their use of domestic space, and their questioning of its boundaries. Representations of the house as a space of women's confinement or, on the contrary, of women's creativity are quite frequent in European and North American art of the late 60s and 70s engaging with feminist politics. Even if the works of Maiolino, Geiger and Parente partly connect with this production, whose 
radical charge is indisputable, their relation to Brazilian cultural production and historical and geo-political context of creation is crucial. Indeed, one should not underestimate the fact that, as Almeida and Weis put it, "In regimes of force, the limits between the public and private dimensions are more imprecise and fluid than in democracies. And although authoritarianism tries to restrict autonomous political participation and promote demobilization, resistance to the regime inevitably drags politics into the private sphere"16 (ALMEIDA and WEIS, 1997: 327).

Relying on heterogeneous esthetic strategies and using different media, the artworks $A$ Espera $^{17}$ (1967_2000) by Maiolino[fig.1],Preparação ${ }^{18}$ (1975) by Parente[fig. 2, 3], and Arte e Decoraçãa ${ }^{19}(1975)$ by Geiger [fig. 4, 5, 6], turn the banality of everyday domestic space into a site of resistance and, possibly, political dissent. In the works explored here, the very construction of home as a place frequently identified with female isolation and stereotyped femininity - but also, in a wider sense, home as "[...] an illusion of coherence and safety based on the exclusion of specific histories of oppression and resistance, the repression of differences even within oneself" (MOHANTY and MARTIN, 2003: 90) - is destabilized in various ways, and eventually imagined also as a problematic and conflicting site of intervention and agency.

\section{Home, as seen from the street}

Fig. 1. Anna Maria Maiolino, A Espera (1967/2000)

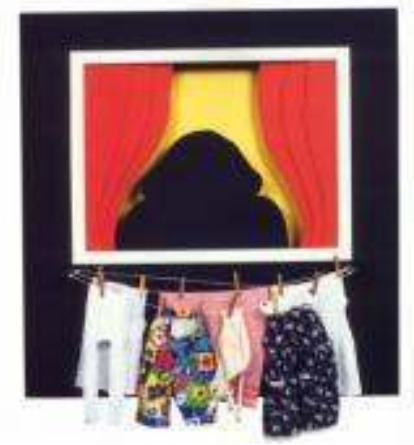

Wood, acrylic ink, rope and cloth. 128x123×30 cm

Coll. Ella Fontanals Cisneros (c) Anna Maria Maiolino

9 A Espera, a wooden relief first created by Anna Maria Maiolino in 1967, materializes a silhouette standing by a window. Some real clothes are hung outside to dry: mainly children garments, but also a bra and a kitchen towel. The bright colors of the clothing, its multiple patterns, as well as the vivid interior decoration, red and yellow, emphasizes the blackness of the silhouette and of the wall enclosing it. In a similar way, the distinct materiality of the textiles placed outside the relief calls attention to the wooden object itself. Here, the traditional boundaries of the space of representation are in fact extended or exceeded in a very playful way.

Engaged with a questioning of modernist painting that leads to tri-dimensionality and to the depiction of everyday reality, Maiolino's work is to be read in the context of the new figurative tendencies emerging in the Brazilian vanguard art in the mid $60 \mathrm{~s}^{20}$ - in dialogue with Brazilian neo-concrete art and popular culture but also, in a more 
problematic way, with the aesthetics of pop and European neo-figurative movements. A Espera is part of an early group of pieces by Maiolino exploring female experience and, in particular, love and family life, and is contemporary of a series of works - as $O$ Héroi $^{21}$ (1966) - critically referring to the country's political situation. As emphasized by the artist herself, questions related to women's experience and to "military repression" were both part of her everyday life at that time (Maiolino in TATAY, 2010: 41).

11 As for the anonymous figure waiting at the window in A Espera, it is, according to the critic Paulo Herkenhoff, a woman "[...] looking for her homecoming husband. It is a weaving of spaces of desire and subjectivity: a combining of the house and the street, the domestic and the public" (HERKENHOFF, 2002: 328). Presenting the partition of space - and the division of labor - as gendered, Maiolino's work locates the female body on the threshold of the house. And yet, this is a window, not a door, and the female character stands undeniably inside. Nevertheless, it seems to me that A Espera, as a configuration of a point of multiple intersections, actual and virtual, between private and public space, implies a specific "space-off". I am using here a term from film theory adopted by Teresa de Lauretis to signify "[...] the space not visible in the frame but inferable from what the frame makes visible" (DE LAURETIS, 1987: 26).

In A Espera, the real clothesline and garments exceed the wooden relief thus pointing to another place onto which the dwelling extends: the urban street, where public and private, individual and collective itineraries meet, where the personal intrudes into the political and vice versa. In particular, the street as a fictional "space-off" connects $A$ Espera to a whole series of artworks and events - produced in Brazil in the late sixties which, as Aracy de Amaral puts it, "take the city as support" in order to "break" the "isolationism" of the individual artist, promote collective creation and the implication of a large and socially diverse audience (DE AMARAL, 1984: 328-329). But, at the same time, A Espera also seems to infer the gallery or the museum as a possible "space-off", a place in which the artwork should engage with the spectators by abandoning its idealized position. In this sense, Maiolino's work holds a significant political subtext. It not only unveils the position attributed to women by a patriarchal society in which spaces of production and reproduction are often considered separate, but also proposes a mode of spectatorship that insists on the sharing of a common space as a primary condition of communication.

Furthermore, I suggest that the latency of specific "spaces-off" materializes the permeability of the boundaries between the home - marginalizing though protecting and public space - open and dynamic but also marked by political control. This is a perspective on the home - and more specifically on women's presence and role in its material and conceptual making and unmaking - that does not try to reduce conflicts or ambiguities. As in a domestic "theatre box", the female figure assists to the spectacle of the world outside, while she is presented as a character on a stage ${ }^{22}$ - perhaps the stage of a marionette theatre as suggested by Paulo Herkenhoff (HERKENHOFF, 2002: 328). In A Esperathe window as a "theatre box" overlooking the outside world becomes a stage inside the art gallery (see COLOMINA, 1992). However, by depicting a female silhouette looking outside of a window onto the street and, of course, onto the exhibition space, Maiolino's work not only theatralizesthe representation, but it alsoappropriates and literally subverts the well-known metaphor of painting as a "window overlooking the world" (see MASHECK, 1991). This is a leitmotif in Western art history, a discipline whose canon has longtime been dominated by male artists. 
In Maiolino's work, Alberti's metaphor is reconfigured in historically excluded territories: the traditionally feminine field of the domestic, and the political and cultural context of what has long been considered a peripheral country. In A Espera, the window is the painting - or rather the painting turned object - and looking at it means above all, for the public, to look at a mise en abîme of painting as a situated perspective from which to view, imagine or represent the world. Thus, the political charge of this work does not only consist in affirming the critical value of a then "[...] socially excluded theme" (Maiolino in TATAY, 2010: 41) but also in confronting the public to the very texture of its own (everyday) gaze, that the object reflects as a distorting mirror. It seems to me that, engaging with A Espera, the spectator is silently invited to consider her/his own perspective when looking at the "space-off" of her/his own political, social and cultural location and to question her/his positioning as one of accountability - one always embedded in that very location.

\section{At home, preparing to leave}

Fig. 2 and Fig. 3. Letícia Parente, Preparação I, 1975 (video still)
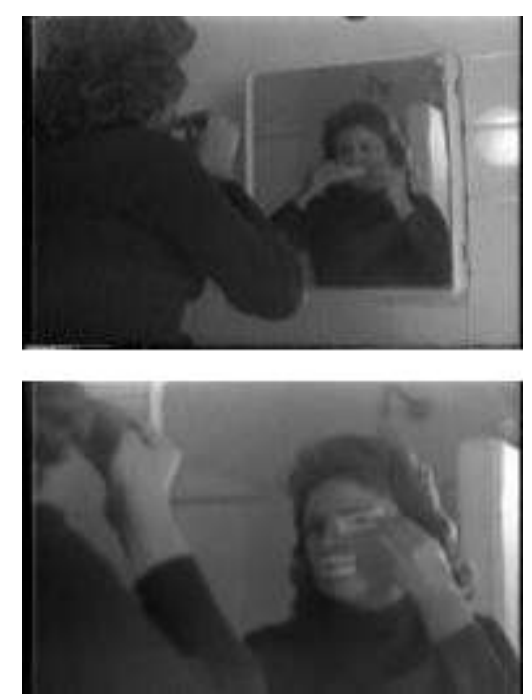

Video, 3'30", Porta-pack 1⁄2 inches. Camera: Jom Tob Azulay (c) Letícia Parente. Courtesy André Parente

The relation between the female body and domestic space is performed by artist LetíciaParente in many of the videos that she created in the mid-seventies. Together with a group including, among others, Anna Bella Geiger, Sonia Andrade and Fernando Cocchiarale, LetíciaParente belongs to the first generation of Brazilian artists experimenting with video. As observed by Arlindo Machado, video art produced by this pioneering generation consisted mainly in "recordings" of the artists' performances and "The basic device was almost exclusively the confrontation between camera and artist [...]" (MACHADO, 1996: 226). In 1975, Parente, an artist as well as a scientist, created a video work titled Preparação I, shot in a domestic interior. The artist stands in front of a mirror, in a bathroom, and gets ready to leave the house. Instead of applying make-up, she covers her eyes and mouth with bandages, then, with an eye pencil, draws open eyes and mouth on the white surfaces. Finally, blinded and silenced, she takes her bag and goes out. Parente herself wrote about this video: "Relation of the artist 
as an individual, through her body, with the socio-political context and its consequences. Above all, the oppression and the censorship against lucidity and speech are present [...]" 23 (PARENTE, 1975). Interestingly, Preparação I relies on the ordinary activity of applying make-up traditionally practiced as a way to enhance femininity or to transform oneself - to refer to the conditions of living and making art in a specific situation of repression. If makeup can create a mask for women to be worn in public - and for actors to be worn on stage-, Parente's work discloses the concealing function of cosmetics while paradoxically increasing its power to hide and transform physical appearance.

As Anna Maria Maiolino's object A Espera, this work also focuses on the boundaries of domestic space: the spatio-temporal configuration recorded by the camera is that of a movement out of the house, a border crossing. The trajectory is announced by the ritual act of making oneself ready and then performed by the artist who leaves the room disappearing from the field of vision. But here, as opposed to A Espera, our very field of vision, defined by the position of the camera, is always inside the house, a location possibly designed to induce a sense of confinement or claustrophobia. At the same time, the trajectory of the female character suggests an ambiguous "space-off", an outside - a city, a country or public space in general - in which wearing a mask is a necessary and banal precaution. In this sense, although the boundaries between inside and outside space are permeable, passing from one to the other literally requires a certain "preparation".

The mirror plays a significant role in Preparação I. At the beginning of the video, the image of the artist's face is in fact captured by the camera through the reflection of the mirror in which she is looking at herself. This process of looking at oneself paradoxically corresponds to a process of undoing subjectivity. The aim is to become invisible, to camouflage in the outside world. If the material and symbolic inscription of power onto the personal and collective body is effectively explored by Parente in MarcaRegistada $^{24}$ (1975), a well-known video in which the artist embroiders the words "Made in Brasil" on the skin under her foot, in Preparação I the strategy chosen by the artist seems related to mimicry.

Reflecting on the boundaries of corporeality, feminist philosopher Elizabeth Grosz refers to Roger Caillois' researches on spatiality and in particular on the phenomenon of mimicry in the natural world. In a text written in the thirties, Caillois relates in fact the practice of mimicry in insects to a form of psychosis known as "psychastenia", in which the subject cannot locate him/herself in space and by consequence cannot draw any boundaries between him/herself and space. As commented by Grosz, "The psychotic and the insect renounce their right to occupy a perspectival point, abandoning themselves to being located, for themselves, as others, from the point of view of others. The primacy of the subject's own perspective is replaced by the gaze of another for whom the subject is merely a point in space, not the focal point organizing space" (GROSZ, 2001: 39). In Parente's video, abdicating one's own perspectival point, becoming silent and blind, an object for others to view, in space, is an everyday strategy of survival. Interestingly, the gaze of the spectator, materialized by the controlling eye of the camera, induces identification with the female character while also forcing him/her to occupy, especially in the final part of the video, the master position of those who control and scrutinize. In this sense, a reflection on video as a medium of both creation and ideological mass control mainly through television ${ }^{25}$ - is a significant subtext of this work. 
menting with irony on the psychotic behaviors produced by political oppression, and on the way institutional control can infiltrate the private sphere, Preparação I should also be read in combination with another video, Preparação $I^{26}$, created in 1976. In this later work, the preparation consists in getting ready to leave the home, referring now to the country and not to the house. The artist gives herself four injections. After each shot she fills up an international sanitary control form to leave Brazil. Each time, she writes down one the following words: "anti cultural colonialism", "antiracism", "anti political mystification" and "anti art mystification" 27 (PARENTE, n.d.). These vaccines should protect the traveler from "illnesses" that are present well beyond the frontiers of Brazil. Thus, as Katia Maciel indicates in her beautiful text about the work of Parente, this video seems to articulate "[...] a criticism of the political context beyond Brazilian borders" (MACIEL, 2011). As observed by Maciel, "Once again the artist uses her own body as the support for the manifesto - as if vaccines could prevent the worst evils among us" (Ibidem).

If the association of Preparação I and II in a series may disclose a desire to explore different points of intersection and movement between inside and outside space between home as dwelling and public space, between home as nation and space beyond its borders -, the body is always presented as a primary site of resistance. As "[...] the locus of the self and the site where the private domain meets the public, where the social is negotiated, produced, and made sense of " (JONES, 2000:20), the body performs here a silent and, above all, non spectacular form of resistance, based on the predictability of everyday gestures: the subtle dislocation of the rituals involving the very passage from one place to the other, from an inside to an outside, and the necessary, and often problematic, negotiation between the two.

\section{Not at home, in the house though}


Fig. 4, Fig. 5, Fig. 6. Anna Bella Geiger, From the series Arte e decoração. 0 artista deve ser criado num ambiente cultural elevado, 1975
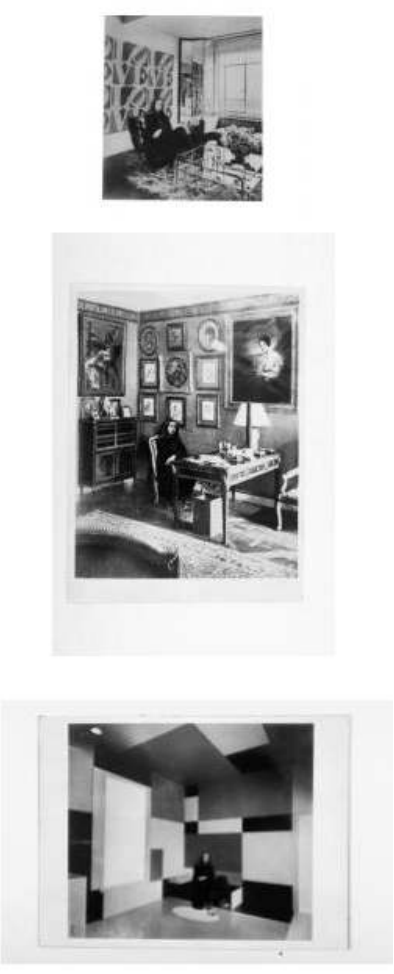

Photomontage. 23x17 cm (Fig. 4 and 5) and 17x19 cm (Fig. 6)

(C) Anna Bella Geiger

At last, I intend to consider a series of works by Anna Bella Geiger, whose words I have quoted in the beginning of this text. One of the most influential artists and teachers of her generation, Anna Bella Geiger begins her trajectory by committing to engraving, then turns, in the early seventies, to conceptual practices while exploring a variety of media. In 1975, she creates a series of photomontage works titled Arte e decoração and subtitled $O$ artista deve ser criado num ambiente cultural elevado ${ }^{28}$. In order to produce them, she cuts silhouettes from pictures of herself taken in Brazil and then recontextualizes them by introducing her figure into photographic images of interiors taken from magazines of home decoration ${ }^{29}$. In one of the works ${ }^{30}$ the artist sits on what looks like a Barcelona chair by Mies van der Rohe, in a modern interior. An artwork, seemingly by artist Robert Indiana, hangs on the wall behind her. In another photomontage, she is seated on a chair in front of a desk in an interior, probably a nineteenth century cabinet. In a third one, Geiger sits on a bed in the (unrealized) Salon de Madame B. designed by Piet Mondrian for the German collector Ida Bienert in $1926^{31}$.

Through their material process of creation, these artworks seem to engage, to a certain extent, with the long and radical tradition of twentieth century critical art, but, most importantly, they connect, through their political charge and their combined use of poor and ordinary materials - popular media and personal iconography -, with the conceptual panorama of the Brazilian art of the seventies. Interestingly, TadeuChiarelli distinguishes these works from Dada and Surrealist photomontage while drawing an analogy with more "vernacular" productions. He particularly refers to the patriotic 
collages that Brazilian pupils were invited to realize for specific commemorations related to the cult of the nation, during the military regime (CHIARELLI, 2007: 83).

In Arte e decoração, as in other works from this period, Anna Bella Geiger raises questions that are capital to her artistic practice: what does it mean to be a female artist from a peripheral country oppressed by a military regime, in a world generally dominated by men and by western cultural models? And what does peripheral country mean exactly? And also, as pointed out by Chiarelli, "Where to fit as an artist, and a woman, in an institution which only values, in its canonical territory, men born white in hegemonic countries?" ${ }^{22}$ (CHIARELLI, 2007: 82). By juxtaposing heterogeneous fragments, the artist undermines the very system of signs from which she would traditionally be excluded. Hence, she opens spaces of discrepancy and doubt. Did these privileged and secure domestic environments construct themselves through the exclusion of others? Did they construct themselves by producing otherness? Which role does art play in these representations and in the set of values they convey? The re-inscription of what may be considered as the other, in Geiger's photomontages, - the woman, the nonwestern, the Latin American -, ironically produces a series of collisions and dislocations. The artist is here in a house but definitely not at home, as easily revealed by montage itself.

In an upper class living room, a young woman sits comfortably on a chair, inactive. She literally plays the role of the femme d'interieur, but she is an artist, as suggested by the title. The interior decoration conveys a deep sense of wealth and at the same time a taste for collecting artworks. With great probability, two Western male artists, Robert Indiana and Mies van der Rohe, are the authors of some very well known artworks in the room. In another photomontage, the cabinet reminds a traditionally gendered division of space. The third photomontage evokes a project in which the creativity of an influential male artist responded to the domestic necessities of a female art collector. One easily remarks here that, if home decoration, as an activity, has often been considered a feminine practice, in these rooms great art seems to be the prerogative of men. Interestingly, this series, along with Diario de um artistabrasileiro ${ }^{33}$ (1975), is one of the works by Geiger that engages more explicitly with questions of gender, without dissociating it, though, from problems related to the hegemony of specific cultural models.

Furthermore, Art and Decoration effectively questions the distance and the differences, in terms of class, race, gender and location, between those who produce art and those who traditionally consume it. If the artist is not always brought up in a "culturally elevated environment", many of those who can afford to buy art are. In this sense using alternative media, cheap and easily distributed, also means to explore the role of the artist, and the function of art itself in the Brazilian social and political context of the seventies, certainly an important aspect of Geiger's work in those years. It also means to imagine other ways in which the relations between artist, work and spectatorship could be reconfigured in such a challenging context.

Regarding, more specifically, domestic space, it seems to me that Arte e decoração significantly troubles - through the articulation of the visual paradox at home/not at home - the rhetoric of the photographic images it appropriates, thus questioning the notions of belonging/not belonging inherent to the very definition of home as the site where one has his/her own place. Discussing several feminist texts concerned with home (among which MOHANTY and MARTY, 2003), Iris Marion Young underlines how 
these authors criticize the construction of home as an illusion of unity, stable identity, "withdrawal from politics" and safety often produced at the expense of others and through the exclusion of others. According to Young, "Martin and Mohanty, de Lauretis and Honig, are right to criticize the bourgeois-dominative meaning of home [...]. They are also right to fear the nostalgic seduction of home as a fantasy of wholeness and certainty. [...] They are right, finally, to suggest that the attempt to protect the personal from the political through the boundaries of home more likely protects privilege from self-consciousness, and that the personal identities embodied in home inevitably have political implications" (YOUNG, 2005: 148-149).

Without following the further developments of Young's argument, one may say that Geiger's photomontages work with, and against, the possibility for "fantasies of wholeness" mobilized by the home to remain intact. Whereas the economic wealth and the (Western) culturally elevated taste of these interiors suggest security, education and sophistication, the grafting of the female body - apparently confirming these values as she first seems to be at home - shows in reality that these images and their promise of self-sufficiency - a full protection from the political, from the street, from the peripheries and from outside in general - is misleading. The ironic inscription of the excluded subject threatens their functioning: she is not at home, finally.

\section{In/Out} labor, and cultural and political marginality or dependency. Indeed, the interplay of the material configuration of these positions, the investigation of art as an institution, and the diverse exploration of the relations between art and spectatorship, is core to these works ${ }^{34}$. As observed by Zanna Gilbert, critical art, according to philosopher Jacques Rancière, negotiates between two ways of conceptualizing art: as separated from other forms of social life and experience and as unseparated from it. According to Rancière,

This negotiation must keep something of the tension that pushes aesthetic experience toward the reconfiguration of collective life and something of the tension that withdraws the power of aesthetic sensoriality from the other spheres of experience. From the zones of indistinction between art and life it must borrow the connections that provoke political intelligibility. And from the separateness of artworks it must borrow the sense of sensory foreignness that enhances political energies (RANCIÉRE, 2009: 41, cit. in GILBERT, 2009).

In these works of Maiolino, Parente and Geiger, "political energies" are "enhanced" by the heterogeneous interconnections established between everyday female experience - in the spatial configurations of domesticity - and ordinary situations of oppression and 
marginalization. It is, I think, the collage of home as one's dwelling and home as one's country that creates "foreignness" and stimulates questioning. At the same time, specific aesthetic strategies that mobilize spectatorship in a critical way and question the role of art in collective emancipation are also crucial here. Drawing on the specificity of the aesthetic experience, these works open spaces of "lucidy and speech", to quote artist Letícia Parente (PARENTE, 1975).

\section{BIBLIOGRAPHY}

ALMEIDA, Maria Hermínia Tavares De \& WEIS, Luiz. "Carro-zero e pau-de-arara: o cotidiano da oposição de classe média ao regime militar". In, SCHWARCZ, Lilia Moritz. (org), História da vida privada no Brasil: contrastes da intimidade contemporânea, v. 4. Companhia das Letras, São Paulo, 1997, 320-409.

BUARQUE DE HOLLANDA, Heloisa \& GONÇALVES, Marcos A. Cultura e participação nos anos 60. Brasiliense, São Paulo, 1986. First ed. 1982.

CHIARELLI, Tadeu. "Anna Bella Geiger: Outras anotações para o mapeamento da obra”. Ars, vol.5, n. 10, 2007, 80-89. https://www.scielo.br/pdf/ars/v5n10/08.pdf [26 Junho 2013]

COLOMINA, Beatriz. “The Split Wall: Domestic Voyeurism”. In COLOMINA, Beatriz (ed.). Sexuality and Space. Princeton Architectural Press, New York, 1992, 73-128.

DE AMARAL, Aracy. Arte paraquê ?A preocupação social na arte brasileira 1930-1970. Subsídio para uma história social da arte no Brasil. Nobel, São Paulo, 1984.

DE LAURETIS, Teresa. Technologies of Gender. Indiana University Press, Bloomington, 1987.

DUNN, Christopher. "The Tropicalista Rebellion, A conversation with Caetano Veloso". Transition, n.70, 1996, 116-138.

GILBERT, Zanna. "Ideological Conceptualism and Latin America: Politics, Neoprimitivism and Consumption". Rebus, n. 4, Autumn/Winter, 2009. www.essex.ac.uk/arthistory/rebus/PDFS/Issue 4/Gilbert.pdf [8 August 2012]

GROSZ, Elizabeth. "Lived Spatiality (The Spaces of Corporeal Desire)". In, Architecture from the Outside, Essays on virtual and real space. The M.I.T. Press, Cambridge (MA), 31-47.

HERKENHOFF, Paulo. “Maiolino's Trajectory: A Negotiation of Differences”. In DE ZEGHER, Catherine (org.). Anna Maria Maiolino Vida Afora. Exib. Cat. The Drawing Center, New York, 2002, 327-343.

JAREMTCHUK, Daria. Anna Bella Geiger: Passagens conceituais. Editora da USP, São Paulo; C/Arte, Belo Horizonte, 2007.

JONES, Amélia. “Survey”. In WARR, Tracey (dir.), The Artist's Body. Phaidon, London, 2000, 16-47. MACHADO, Arlindo. "Video Art: The Brazilian Adventure". Leonardo, vol. 29, n. 3, 1996, 225-231. MACHADO, Vanessa Rosa. Lygia Pape, espaços de ruptura. Annablume, São Paulo, 2010. 
MACHADO, Vanessa Rosa. “Arte e espaço público nos filmes de Lygia Pape”. Risco, Revista de pesquisa em arquitectura e urbanismo, iau/usp, 7, 2008, 93-106. www.arquitetura.eesc.usp.br/ revista_risco/Risco7-pdf/02_art07_risco7.pdf[26 June 2013]

MACIEL, Katia. The body is the measure of the house, 2011. In, leticiaparente.net/English/index.htm [26 June 2013]

MASHECK, Joseph. “Alberti's 'Window': Art-Historiographic Notes on an Antimodernist Misprison”. Art Journal, Vol. 50, No. 1, Constructed Painting, Spring, 1991, 34-41.

MOHANTY, Chandra; MARTIN, Biddy. "What's Home Got to Do with It? (with Biddy Martin)”. In MOHANY, Chandra.Feminism without borders, Decolonizing theory, Practicing solidarity. Duke University Press, Durham \& London, 2003, 85-105.

MORAIS, Frederico. "O corpo é o motor da obra". In Artes plásticas, a crise da hora atual. Paz e Terra, Rio de Janeiro, 1975, 24-34.

MORETHY COUTO, Maria de Fátima. "Vanguarda e subdesenvolvimento ou a arte da guerrilha e o artista como guerrilheiro”. In CONDURU, Roberto; SIQUEIRA, Vera Beatriz (org.), Trânsitos entre criação, crítica e história da arte, Anais do XXX Colóquio do Comité Brasileiro de História da Arte, Rio de Janeiro/Petrópolis, 2010, 1209-1215. maria_art.pdf [26 June 2013]

O'DOHERTY, Brian. Inside the White Cube, The Ideology of the Gallery Space. The Lapis Press, San Francisco, 1986.

OITICICA, Hélio. Esquema geral da nova objectividade, 1967. In PECCININI, Daisy (org.). Objeto na arte: Brasil anos '60. Fundação Armando Alves Penteado São Paulo, 1978, 75-81.

PARENTE LETÍCIA (1975): Proposta de seriação de trabalhos / Proposal of serial works. In leticiaparente.net [13 August 2012]

PARENTE LETÍCIA (not dated): Proposta geral da obra em vídeo. In leticiaparente.net [13 August 2012]

PECCININI, Daisy. Figurações, Brasil anos 60. EDUSP/ Itaú Cultural, São Paulo, 1999.

RANCIÉRE, Jacques. "Contemporary Art and the Politics of Aesthetics”. In HIDERLIER B., KAIZEN W., MAIMON V., MANSOOR J., MCCORMICK S. (ed.). Communities of Sense: Rethinking Aesthetics and Politics. Duke University Press, Durham and London, 2009, 31-50.

SCOVINO, Felipe. Anna Bella Geiger (interview). In SCOVINO, Felipe (org.).Arquivo contemporâneo, 7Letras, Rio de Janeiro,19-37.

SCHWARZ, Roberto. “Cultura e politica no Brasil: 1964-1969”, 1970. In BASUALDO, Carlos (org.). Tropicália, uma revolução na cultura brasileira. Cosac Naify. São Paulo, 2007, 279-308.

SÜSSEKIND, Flora. "Coro, contrários, massa: a experiência tropicalista e o Brasil de fins dos anos 60". In BASUALDO, Carlos (org.), Tropicália, uma revolução na cultura brasileira. Cosac Naify, São Paulo, 2007, 31-56.

TATAY, Helena. “A Conversation between Anna Maria Maiolino and Helena Tatay”.In TATAY, Helena (org.).Anna Maria Maiolino. Cat. exhib. FundacióAntoniTàpies / Koenig Books, London: 2010, 38-60.

TROY, Nancy J. “Mondrian's Designs for the Salon de Madame B..., à Dresden”. The Art Bulletin, vol. 62 , n. 4, Dec. 1980, 640-647. 
YOUNG, Iris Marion. "House and Home: Feminist Variations on a Theme". In On Female Body Experience, "Throwing Like a Girl" and Other Essays, Oxford University Press, Oxford and New York, 2005, 123-154. First published in 1997.

\section{NOTES}

1. "Participar enquanto artista na passagem da década de 1960 para 1970 era lidar com outra realidade : um novo mundo, social, político, económico e cultural. Um mundo no qual as ideias da modernidade abstracta já não pareciam dar conta". Unless indicated, all translations from Portuguese in the text are by the author.

2. This engagement with the reality of the country under the military rule is quite distinct from the strategies and activities of artists and intellectuals associated with the CentrosPopulares de Cultura in the beginning of the sixties. On this aspect see B. DE HOLLANDA \& GONÇALVES: 1986 and DE AMARAL: 1984.

3. "New Brazilian Objectivity".

4. "[...] a formulação de um estado típico da arte brasileira de vanguarda atual".

5. "[...] abordagem e tomada de posição em relação a problemas políticos, sociais e éticos".

6. "[...] pura contemplação transcendental [...]".

7. "No Brasil [...] hoje, para se ter uma posição cultural atuante, que conte,tem-se que ser contra, visceralmente contra tudo que seria em suma o conformismo cultural, politico, ético, social".

8. As musician Caetano Veloso puts it, “[...] we rejected the role of a Third World country living in the shadows of more developed countries. Through our art we wanted to put forward a vision of the world at that time, from our own perspective as Brazilians" (Caetano Veloso in DUNN, 1996: 121). Concerning the "rediscovery" of Oswald de Andrade's cultural anthropophagy or "superanthropophagy" see OITICICA, 1967: 75, and SÜSSEKIND, 2007: 32-37.

9. [...] quando o estudante e o público dos melhores filmes, do melhor teatro, da melhor música e dos melhores livros já constitui massa politicamente perigosa [...]".

10. 'If in 64 it had been possible for the right-wing to 'preserve' the cultural production, as it was enough to get rid of its contact with the working and rural mass, in 68, when the student and the public of the best films, theatre plays, music and books already constitute a politically dangerous mass, it will be necessary to replace or censor the professors, the theatre directors, the writers, the musicians, the books, the editors. In other words, it will be necessary to get rid of the very living culture of the present. The government has already taken various steps in this direction, and one does not know how many more it will take" (SCHWARZ, 1970: 280-1). "Se em 64 fora a possível à direita 'preservar' a produção cultural, pois bastara liquidar o seu contacto com a massa operária e camponês, em 68, quando o estudante e o público dos melhores filmes, do melhor teatro, da melhor música e dos melhores livros já constitui massa politicamente perigosa, será necessário trocar ou censurar os professores, os encenadores, os escritores, os músicos, os livros, os editores - noutras palavras, será necessário liquidar a própria cultura viva do momento. o governo já deu vários passos neste sentido, e não se sabe quantos mais dará."

11. "Bússola Salon".

12. "From the Body to the Earth".

13. "Sundays of Creation".

14. The censoring of some art exhibitions, for example, induced the national and international artistic community, in 1969, to start a boycott to the São Paulo Biennial.

15. On this see MORETHY COUTO, 2010.

16. "Nos regimes de força, os limites entre as dimensões pública e privada são mais imprecisos e movediços do que nas democracias. Pois, embora o autoritarismo procure restringir a participação politica autônoma e promova a desmobilização, a resistência ao regime 
inevitavelmente arrasta a politica para dentro da órbita privada". Vanessa Rosa Machado also refers to Almeida and Weis' text (although she focuses on different aspects of it) in her exploration of LygiaPape's work and its engagement with public space. See MACHADO V., 2008 and 2010.

17. Waiting.

18. Preparation I.

19. Art and Decoration.

20. See PECCININI, 1999.

21. The Hero.

22. This reading is certainly informed by Beatriz Colomina's exploration of the "theatre box" in Loos' interiors. Colomina: 1992.

23. We partly modified the translation present in the artist's web site, leticiaparente.net. "Relação da pessoa da artista, através de seu corpo com o contexto político-social e suas conseqüências. Presente sobretudo a opressão e a censura à lucidez e à fala".

24. Trademark.

25. In this sense, see MACHADO, 1996: 225.

26. Preparation II.

27. "anticolonialismo cultural”, "antiracismo", "anti mistificação política", "anti mistificação da arte".

28. Art and Decoration, The Artist has to be brought up in a culturally elevated environment.

29. According to DariaJaremtchuk, the artist first photographed the selected pages of home magazines. Then, she realized the montage by inserting her own photographic image in the picture. (JAREMTCHUK, 2007: 116). Jaremtchuk's in-depth reading of Geiger's conceptual production has been an important resource for approachingthe artist's work.

30. As indicated by Geiger, the piece is composed by 6 images (photomontage works). E-mail correspondence with the artist, July 2013.

31. The photograph used by Geiger is a picture of the full-scale Formica model produced by the Pace gallery in New York in 1970. The picture is also reproduced in O'DOHERTY, 1986: 84. See TROY, 1980: 640.

32. "Onde se inserir enquanto artista e mulher numa instituição que apenas valoriza em seu território canónico homens nascidos brancos em países hegemónicos ?".

33. Diary of a Brazilian artist. It should be noted that in the original title Geiger uses the masculine. 34. On "ideological conceptualism" and the problems in separating form from content, see GILBERT, 2009. I will refer here to the same passage by Jacques Rancière that Zanna Gilbert discusses in her article.

\section{ABSTRACTS}

This text elaborates a close reading of three artworks created in Brazil in the late sixties and seventies, A Espera (1967-2000) by Anna Maria Maiolino, Preparação I (1975) by LetíciaParente and Arte e decoração (1975) by Anna Bella Geiger. More specifically, the article aims to examine how, in these works, the multiple intersections and negotiations occurring between private and public space are explored by materializing heterogeneous images of the home. These artworks develop an iconography of the domestic, but also mobilize, in a more problematic way, the whole 
polysemic spectrum of the word home. Envisioning the home, and the house, as a site of passage and movement, instead of a protected and self-sufficient place, these works ironically comment on gendered divisions of space and look at how the political constantly infiltrates the private sphere.

Ce texte propose une lecture de trois œuvres d'art créées au Brésil à la fin des années soixante et dans les années soixante-dix: «A Espera » (1967-2000) d'Ana Maria Maiolino; "Preparação I » (1975) de Letícia Parente et «Arte e decoração» (1975) d'Anna Bella Geiger. L'article entend examiner comment, dans ces travaux, les multiples croisements et négociations qui ont lieu entre espace public et privé sont explorés à travers la matérialisation d'images hétérogènes liées à la représentation de la maison. En effet, ces œuvres développent une iconographie de l'univers domestique tout en mobilisant, de façon plus problématique, l'ensemble du spectre polysémique du mot maison. Envisageant le chez-soi et la maison-comme un espace de passage et de circulation, et non pas comme un lieu protégé et auto-suffisant, ces œuvres posent un regard ironique sur les divisions de genre dans l'espace, et explorent comment le politique pénètre sans cesse la sphère privée.

\section{INDEX}

Keywords: art, home, gender, private space, Brazil

Mots-clés: art, maison, genre, espace privé, Brésil

\section{AUTHOR}

\section{GIULIA LAMONI}

FCT Post-doctoral Research Fellow - Instituto de História da Arte, Universidade Nova de Lisboa, Faculdade de Ciências Sociais e Humanas / Fundação para Ciência e Tecnologia Portugal giulialamoni[at]hotmail.com 